\title{
FISH STOCK ASSESSMENT OF PIRAPUTANGA Brycon microlepis IN THE CUIABÁ RIVER BASIN, PANTANAL OF MATO GROSSO, BRAZIL
}

\author{
MATEUS, L. A. de F. ${ }^{1}$ and ESTUPIÑÁN, G. M. B. ${ }^{2}$ \\ ${ }^{1}$ Departamento de Produção Animal, Universidade Federal de Mato Grosso, CEP 78060-900, Cuiabá, MT, Brazil \\ ${ }^{2}$ Centro de Pesquisas em Biologia Aquática, INPA, CEP 69011-970, Manaus, AM, Brazil \\ Correspondence to: Lúcia A. F. Mateus, Departamento de Ecologia, IB, Unesp, \\ CEP 13506-900, Rio Claro, SP, Brazil, e-mail: 1mateus@terra.com.br
}

Received November 27, 2000 - Accepted March 28, 2001 - Distributed February 28, 2002

(With 4 figures)

\begin{abstract}
Fork length measurements of individuals of Brycon microlepis landed and commercialized at the Porto Market in Cuiabá, MT, from May-October 1996 to May-October 1997 were used to estimate growth and mortality parameters for this species. The average estimated populational parameters were: $\mathrm{L}_{\infty}=$ $705 \mathrm{~mm}, \mathrm{k}=0.275$ year $^{-1}, \mathrm{C}=0.775, \mathrm{WP}=0.465, \mathrm{Lc}=164 \mathrm{~mm}, \mathrm{M}=0.585$ year $^{-1}, \mathrm{Z}=0.822$ year $^{-1}$, with $\mathrm{F}=0.237$ year $^{-1}$. Yield per recruit analysis suggests that the stock is not yet overexploited.
\end{abstract}

Key words: Brycon, mortality, yield per recruit, fisheries management.

\section{RESUMO}

\section{Avaliação do estoque pesqueiro da piraputanga Brycon microlepis na bacia do rio Cuiabá, Pantanal Mato-grossense}

Medidas de comprimento furcal obtidas de exemplares de Brycon microlepis desembarcados e comercializados no Mercado do Porto em Cuiabá, MT, no período de maio a outubro de 1996 e de maio a outubro de 1997, foram utilizadas para a obtenção de estimativas dos parâmetros de crescimento e mortalidade da espécie. Os parâmetros populacionais médios estimados foram: $\mathrm{L}_{\infty}=705 \mathrm{~mm} ; \mathrm{k}=$ 0,275 ano $^{-1} ; \mathrm{C}=0,775 ; \mathrm{WP}=0,465 ; \mathrm{Lc}=164 \mathrm{~mm} ; \mathrm{M}=0,585 \mathrm{ano}^{-1} ; \mathrm{Z}=0,822 \mathrm{ano}^{-1}$, sendo $\mathrm{F}=$ $0,237 \mathrm{ano}^{-1}$. A análise do rendimento por recruta e a taxa de explotação indicam que o rendimento máximo sustentável não foi alcançado. Portanto, o estoque ainda não está sobreexplotado.

Palavras-chave: Brycon, mortalidade, rendimento por recruta, manejo de pesca.

\section{INTRODUCTION}

The fundamental purpose of fisheries stock assessment is to provide a background for the elaboration of management plans envisioning optimum long-term exploitation of natural aquatic resources (Sparre \& Venema, 1997; Hilborn \& Walters, 1992). To this end, implementation is necessary of fisheries strategies that render high year-to-year catches.

Studies on yield per recruit have already been developed to evaluate fresh-water fisheries stocks. Petrere (1983), based on data from 1977 and 1978, concluded that the stock of tambaqui, Colossoma macroponum, in Amazonas State was not overfished. However, Isaac \& Ruffino (1996) pointed out the overfishing of this species in Santarém, while Barthem \& Petrere (1995) showed a similar situation affecting the piramutaba Brachyplatystoma vaillantii in the Amazon.

For the Pantanal of Mato Grosso State, where fisheries also have a strong economic importance, little is known about the present exploitation level of fish stocks. Mateus \& Petrere (submitted) evaluated the fishery of pintado (Pseudoplatystoma corruscans) and concluded that this species is not 
yet overfished. However, for other commercially important species, such as the pacú (Piaractus mesopotamicus), cachara (Pseudoplatystoma fasciatum), and piraputanga, among others, there are no available data on the maximum sustainable yield.

The piraputanga is an omnivorous characid of the sub-family Bryconinae (Britski et al., 1999), a species known to undertake periodic upriver migrations associated with reproduction. According to data from the Plano de Conservação da Bacia do Alto Paraguai (PCBAP - Conservation Plan of the Upper Paraguai Basin, 1997), in 1995 this species ranked sixty in the commercial fishery catch in Mato Grosso, when 28.3 tons were captured. However, this figure might have been underestimated, as no systematic accompaniment of fisheries landings exists in this State.

Consumption of piraputanga has been increasing in recent year due to its well-appreciated flavor, and its commercialization has been growing in restaurants around Cuiabá, the capital city of Mato Grosso (MT) where its fisheries have great local economic importance. Nevertheless, basic data about the biology of this species is meager, and information about the present situation of its stock is lacking.

The present study aimed to evaluate the status of the piraputanga in the Cuiabá River Basin, MT, through yield-per-recruit analysis based on length frequency date based on commercial landings in the fish market of Cuiabá.

\section{MATERIAL AND METHODS}

Fork length (LF) measurements in millimeters were obtained from individuals landed and commercialized in the Porto Market in Cuiabá, MT, from May to October of 1996 and 1997. Fork lengths were grouped into frequency distributions tables on a monthly basis for each year, and the mean length was calculated from these tables. Total length (LT) measurements were gathered in order to establish a relationship between LT and LF; this was accomplished by means of a linear regression, accordingly to the model $\mathrm{LT}=\mathrm{a}+\mathrm{b} * \mathrm{LF}$, where $a$ and $b$ are parameters estimated by the regression.

The following estimates of the growth parameters were obtained: $\mathrm{L}_{\infty}=$ asymptotic fork length $(\mathrm{cm}), \mathrm{k}=$ growth coefficient $\left(\right.$ year $\left.^{-1}\right), \mathrm{C}=$ oscillation parameter, and $\mathrm{WP}=$ winter point, i.e., the period where growth slows. These parameters were estimated with the program ELEFAN I (Pauly, 1987) within the FISAT program (Gayanilo et al., 1994).

Estimation of the natural mortality rate was obtained through Pauly's empirical model (Pauly, 1980):

$\ln \mathrm{M}=-0.0152-0.279 \ln \mathrm{L}_{\infty}+0.6543 \ln \mathrm{k}+$

$$
+0.4634 \ln \overline{\mathrm{T}}
$$

where $\mathrm{L}_{\infty}$ is the asymptotic length and $\overline{\mathrm{T}}$ is the mean annual temperature (in ${ }^{\circ} \mathrm{C}$ ), which is assumed to reflect the water surface temperature.

The total mortality rate $(\mathrm{Z})$ was obtained accordingly to the model proposed by Ssentongo \& Larkin (1973):

$\mathrm{Z}=(\mathrm{n} \cdot \mathrm{k} /(\mathrm{n}+1))\left(\ln \left\{\mathrm{L}_{\infty}-\mathrm{Lc} /\left(\mathrm{L}_{\infty}-\overline{\mathrm{L}}\right\}\right)^{-1}\right.$

with the variance of the term $(\mathrm{Z} / \mathrm{k})$ calculated as follows:

$\operatorname{Var}(\mathrm{Z} / \mathrm{k})=\left(\mathrm{n} .(\mathrm{n}+1)^{-2}\right)\left(\ln \left(\left(\mathrm{L}_{\infty}-\mathrm{Lc}\right)\left(\mathrm{L}_{\infty}-\overline{\mathrm{L}}\right)\right)\right)^{-2}$

where $\mathrm{n}$ is the number of fishes sampled, $\mathrm{k}$ is the growth coefficient, $\mathrm{L}_{\infty}$ is the asymptotic length $(\mathrm{cm})$, $\mathrm{Lc}$ is the length of the smallest fish in the sample, and $\overline{\mathrm{L}}$ is the average length in the samples.

The relative yield per recruit (Y'/R) was calculated by the method of Beverton \& Holt (1966) with the FISAT package (Gayanilo et al., 1994), and according to the model:

$$
\begin{aligned}
\mathrm{Y}^{\prime} / \mathrm{R}= & \mathrm{EU}^{\mathrm{M} / \mathrm{k}}\left[1-(3 \mathrm{U} / 1+\mathrm{m})+\left(3 \mathrm{U}^{2} / 1+2 \mathrm{~m}\right)-\right. \\
& \left.\left.-\mathrm{U}^{3} / 1+3 \mathrm{~m}\right)\right]
\end{aligned}
$$

where:

$$
\begin{aligned}
& \mathrm{m}=(1-\mathrm{E}) /(\mathrm{M} / \mathrm{k})=\mathrm{k} / \mathrm{Z} \\
& \mathrm{U}=1-\left(\mathrm{Lc} / \mathrm{L}_{\infty}\right) \\
& \mathrm{E}=\mathrm{F} / \mathrm{Z} \text { (exploitation rate) }
\end{aligned}
$$

\section{RESULTS}

The frequency distribution of the fork length (LF) of the piraputanga during the years of 1996 and 1997 in the Cuiabá River Basin is showed in Fig. 1. In 1996, LF varied from $164 \mathrm{~mm}$ (Lc) to $670 \mathrm{~mm}$, with a mean of $317.5 \mathrm{~mm}$ and a median of $319 \mathrm{~mm}$. In 1997, LF varied from $200 \mathrm{~mm}$ (Lc) to $590 \mathrm{~mm}$, with a mean of $318 \mathrm{~mm}$ and a median of $318 \mathrm{~mm}$. The monthly frequency distribution showed a polimodal pattern. The monthly average LF can be seen in Fig. 2 . 


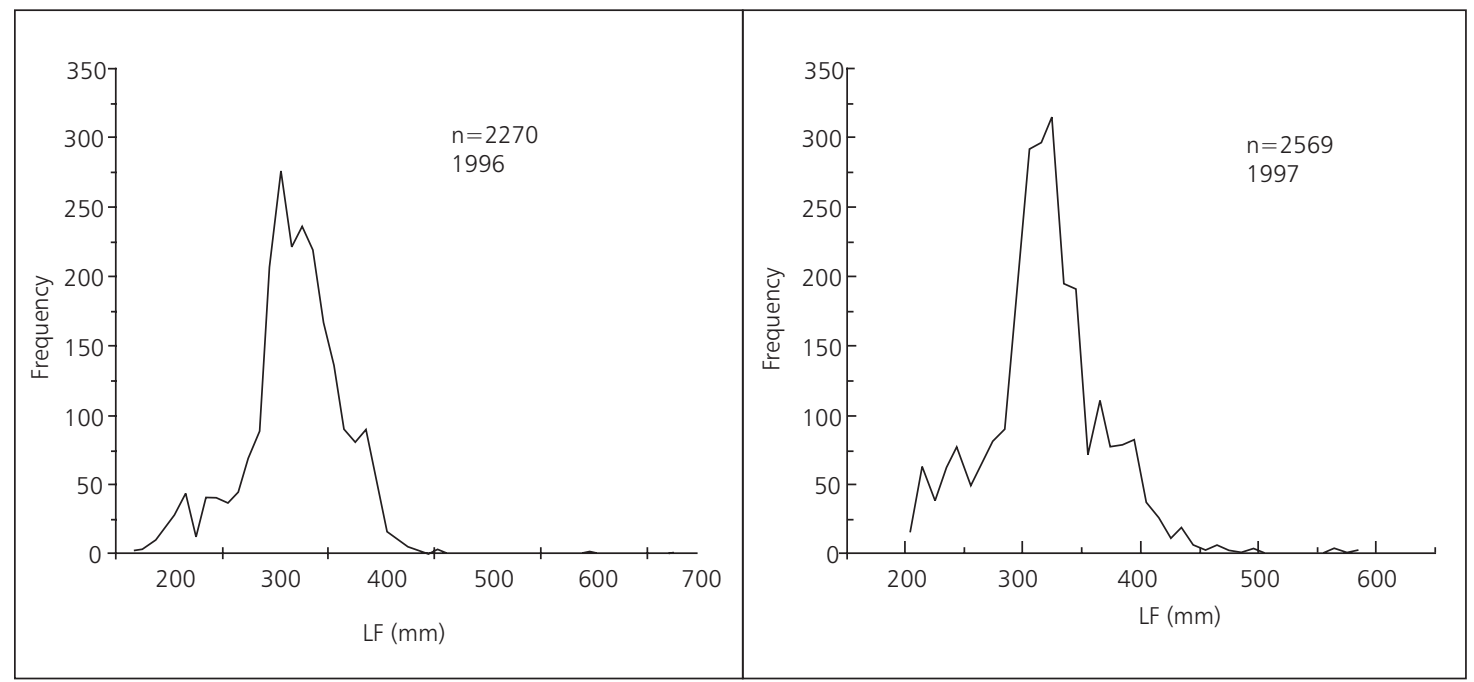

Fig. 1 - Frequency distribution of fork length of the piraputanga Brycon microlepis in the Cuiabá River Basin, Pantanal Matogrossense.

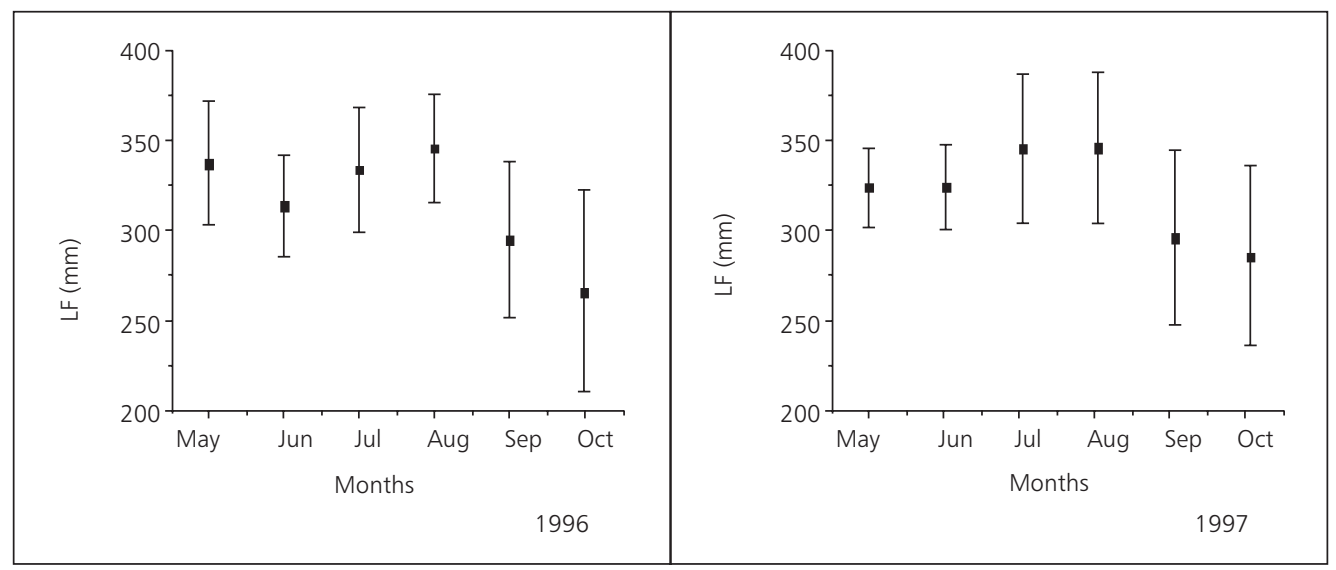

Fig. 2 - Monthly average length during 1996 and 1997 of the piraputanga Brycon microlepis in the Cuiabá River Basin, Pantanal Matogrossense.

The relationship between total and fork length of the piraputanga Brycon microlepis in the Cuiabá River Basin, Pantanal Mato-grossense, can be obtained by the expression: $\mathrm{LT}=16,768+0.983 \mathrm{LF}$, $\mathrm{r}=0.96, \mathrm{n}=130$.

The parameters that describe growth in length of the piraputanga were very similar during 1996 and 1997 (Table 1). The values for $\mathrm{k}$ and $\mathrm{L}_{\infty}$ obtained by the ELEFAN I were respectively 0.28 year $^{-1}$ and $701 \mathrm{~mm}$ for 1996 and 0.27 year $^{-1}$ and $710 \mathrm{~mm}$ for 1997.
The oscillation parameter (C) estimated for 1996 was 0.75 and for 1997 was 0.80 , with the winter point (WP) being equal to 0.50 for 1996 and 0.43 for 1997 .

These results suggest that growth follows a seasonal oscillatory pattern, with a slow growth rate between May and June, a period corresponding to the low water regime of the region.

The growth curves obtained by ELEFAN showed that fisheries operate upon 4 cohorts of the population (Fig. 3). 
TABLE 1

Population parameters of the piraputanga Brycon microlepis in the Cuiabá River Basin, Pantanal Mato-grossense.

\begin{tabular}{|c|c|c|c|c|c|c|c|c|c|}
\hline Year & $\mathbf{L}_{\infty}(\mathbf{m m})$ & $\mathbf{K}\left(\mathbf{y e a r}^{-\mathbf{1}}\right)$ & $\mathbf{C}$ & $\mathbf{W P}$ & $\mathbf{R n}$ & $\mathbf{M}\left(\mathbf{y e a r}^{-\mathbf{1}}\right)$ & $\mathbf{Z}\left(\mathbf{y e a r}^{-\mathbf{1}}\right)$ & $\mathbf{F}\left(\mathbf{y e a r}^{-\mathbf{1}}\right)$ & $\mathbf{E}$ \\
\hline $\mathbf{1 9 9 6}$ & 701 & 0.28 & 0.75 & 0.50 & 0.174 & 0.59 & 0.831 & 0.241 & 0.290 \\
\hline $\mathbf{1 9 9 7}$ & 710 & 0.27 & 0.80 & 0.43 & 0.154 & 0.58 & 0.814 & 0.234 & 0.287 \\
\hline
\end{tabular}
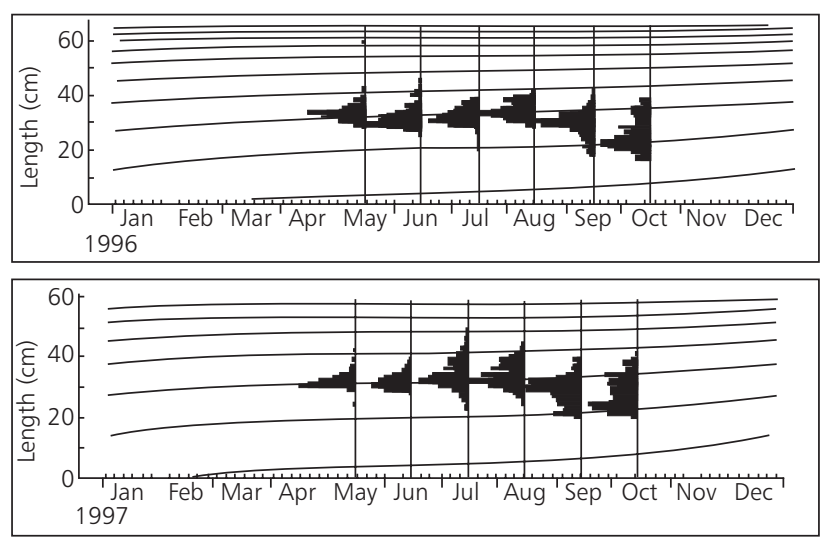

Fig. 3 - Frequency distribution of length and growth curves estimated for the piraputanga Brycon microlepis in the Cuiabá River Basin, Pantanal Mato-grossense, for 1996 and 1997.

The total mortality, Z, estimated with the length at the first catch (Lc) being equal to 164 $\mathrm{mm}$ for 1996 was 0.831 year $^{-1}$ with a $\operatorname{var}(\mathrm{Z} / \mathrm{k})$ equal to 0.0039 . For $1997, \mathrm{Z}$ was estimated as 0.814 years $^{-1}$, with $\operatorname{var}(\mathrm{Z} / \mathrm{k})=0.0036$.

The natural mortality rate, M, during 1996 , with an annual mean temperature of $26.1{ }^{\circ} \mathrm{C}$ was estimated at 0.59 year $^{-1}$. For 1997, when the annual mean temperature was $26.4^{\circ} \mathrm{C}$, $\mathrm{M}$ was estimated at 0.58 year $^{-1}$. Fish mortality, F, was estimated by considering that $\mathrm{Z}=\mathrm{M}+\mathrm{F}$; using this equation, $Z$ was estimated, for 1996 and 1997, as being equal to 0.241 year $^{-1}$ and 0.234 year $^{-1}$, respectively (Table 1).

Yield-per-recruit analysis was carried out using the mean values of the populational parameters between 1996 and 1997, where $\mathrm{L}_{\infty}=705$ $\mathrm{mm}, \mathrm{k}=0.275$ year $^{-1}, \mathrm{Lc}=164 \mathrm{~mm}, \mathrm{M}=0.585$ year ${ }^{-1}, Z=0.822$ year $^{-1}$, and $F=0.237$ year $^{-1}$. Fig. 4a shows the relationship between the yield per recruit and the exploitation rate (E), which denotes the fraction of the population that was effectively removed by fishery (F/Z), for the actual values of M, F, and Lc. E is equal to 0.288 , suggesting that the exploitation rate does not yet reach the maximum sustainable yield. In Fig. 4b, the yield per recruit is plotted against $F$ for different values of $\mathrm{Lc}$, with actual values of $\mathrm{Lc}$ and $\mathrm{F}$ being indicated by an arrow. Fig. $4 \mathrm{a}$ and $\mathrm{b}$ shows that the maximum sustainable yield was not reached. In (a), yield per recruit is demonstrated to have increased as Lc increased, which diminished the risk of overfishing.

\section{DISCUSSION}

By law, the minimum length for catching the piraputanga is $30 \mathrm{~cm}$ (total length). Even so, during all months of 1996 and 1997, individuals below this limit were landed, as evidenced by the relationship between total and fork length. This indicates fishery pressure on young individuals, which in turn may affect recruitment, leading to overfishing. However, data on the size of first 
gonadal maturation are not yet available; this information is essential for establishing a safer minimum catch length as well as for implementing of a management plan for this species.

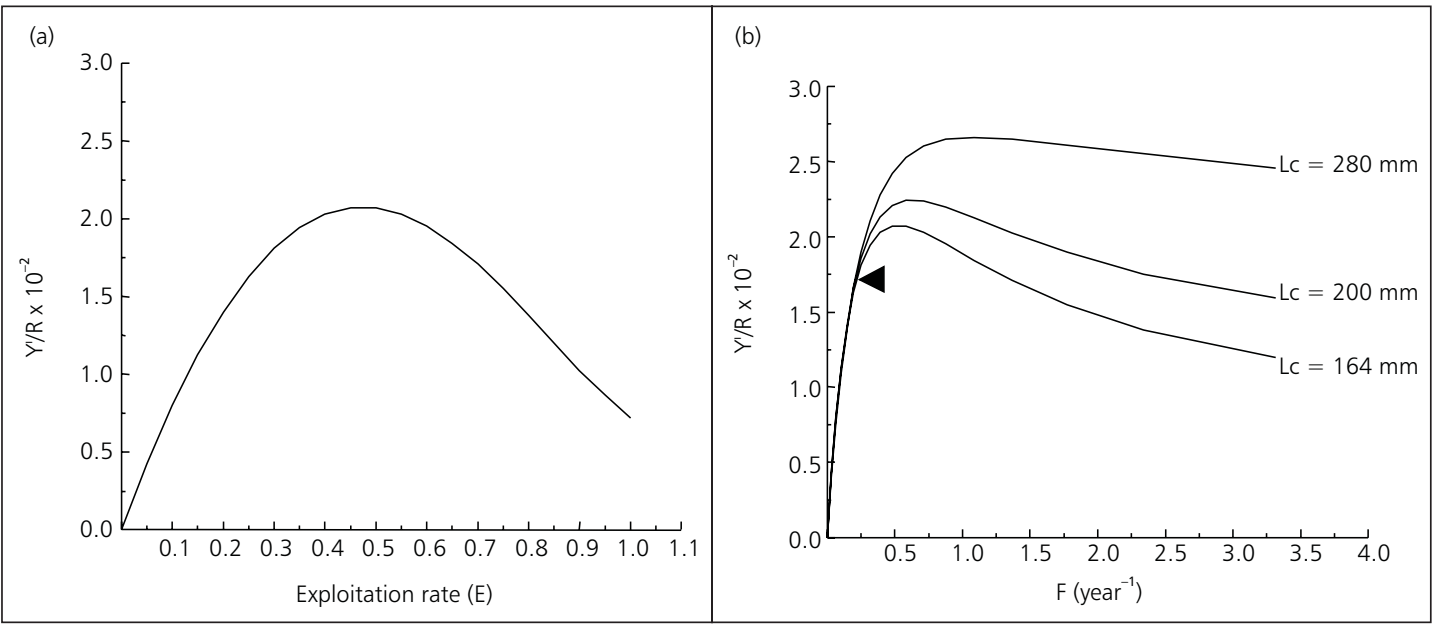

Fig. 4 - (a) Yield per recruit and exploitation rate and (b) yield per recruit and fish mortality (F) of the piraputanga Brycon microlepis in the Cuiabá River Basin, Pantanal Mato-grossense. (4) present value of F.

The piraputanga is an omnivorous species that, based on WP values obtained, shows decreased growth during the lowering period, when schools are returning to the river beds and the feeding area decreases. Moreover, migratory fishes are accumulating reserves for reproductive migration. Studies carried out with other flooding area species indicated diminished growth rate during low water periods (Mateus \& Petrere (submitted); Barthem, 1990; Isaac \& Ruffino, 1996). Food availability is then less in relation to fish density, fish are then restricted to riverbeds, as they lack access to flooded areas for feeding. Increase in growth as the water level rises is suggested as being a response to increased food availability during this period (Lowe-McConnel, 1999), which enables species to accelerate somatic growth and accumulate reserves for reproductive migration (Junk, 1985).

The Beverton \& Holt model of yield per recruit indicates that the stock of Brycon microlepis in the Cuiabá River Basin is not over-fished. Nevertheless, caution should be exercised in using this analysis, as we cannot yet consider other important factors, such as environmental integrity, that can interfere with recruitment, as in the case of Brycon microlepis which depends on flooded areas for reproduction, and marginal vegetation for feeding. Thus, these areas must be preserved in order to maintain the renovation capacity of the fish stocks (Welcome, 1979; Nakatani et al., 1997; Agostinho, 1997).

\section{CONCLUSIONS AND RECOMMENDATIONS}

In this study we concluded that the stock of Brycon microlepis at the present fishing level is not overfished. However, individuals below the minimum legal limit for catch are being exploited, indicating a tendency for catching juveniles by the commercial fishery.

As a management strategy, we suggest:

- reproductive biology studies in order to determine the growth parameters of first gonadal maturation so that a safer minimum length estimation for catch can be established; 
- preservation of flooded areas and riparian vegetation;

- implementation of a collection system of statistical data associated with fishery; this would help to monitor not only the stock of the piraputanga but also of other commercially important stocks so that an adequate management plan could be implemented for the entire wetland region.

Acknowledgments - We would like to thank to Dr. Miguel Petrere Jr. for a critical reading of the manuscript.

\section{REFERENCES}

AGOSTINHO, A. A., 1997, Qualidade dos habitats e perspectivas para a conservação. In: A. A. Agostinho, A. E. de M. Vazzoler \& N. M. Hahn (eds.), A planície de inundação do Alto Rio Paraná. EdUEM, Maringá, PR, pp. 455-460.

BARTHEM, R. B., 1990, Ecologia e pesca da piramutaba (Brachyplatystoma vaillanti). Tese de Doutorado, Unicamp, Campinas, SP, Brasil, 268p.

BARTHEM, R. B. \& PETRERE Jr., M., 1995, Fisheries and population dynamics of Brachyplatystoma vaillanti (Pimalodidae) in the Amazon Estuary. Ann. Woeld Fisheries Congress, Athen, pp. 329-340.

BEVERTON, R. J. H. \& HOLT, S. J., 1966, On the dynamics of exploited fish populations. Fish. Invest., Lond. Series, 2(19), 533p.

BRITSKI, H. A., SILIMON, K. Z. \& LOPES, B. S., 1999, Peixes do Pantanal. CPAP/EMBRAPA, Corumbá, MS, $184 \mathrm{p}$.

GAYANILO Jr., F. C., SPARRE, P. \& PAULY, D., 1994, The FAO-ICLARM Stock Assessment Tools (FISAT) User's Guide. FAO Computerized Information Series (Fisheries) 6, $186 \mathrm{p}$.

HILBORN, R. \& WALTERS, C. J., 1992, Quantitative fisheries stock assessment. Choice, dynamics and uncertainty. Chapman and Hall, London, 570p.

ISAAC, V. J. \& RUFFINO, M. L., 1996, Population dynamics of tambaqui Colossoma macropomum Curvier, in the lower Amazon Brazil. Fisheries Management and Ecology, 3: 315-333
JUNK, W. J., 1985, Temporary fat storage, an adaptation of some fish species to the water level fluctuation and related environmental changes of the Amazon river. Amazoniana, 9(3): 315-351.

LOWE-MCCONNEL, R. H., 1999, Estudos ecológicos de comunidades de peixes tropicais. EdUSP, São Paulo, SP, $534 \mathrm{p}$.

MATEUS, L. A. F. \& PETRERE Jr., M. (submitted) Age, growth and yield per recruit analysis of the pintado, Pseudoplatystoma coruscans AGASSIZ, in the Cuiabá river basin, Pantanal of Mato Grosso, Brazil. Brazilian Journal of Ecology.

NAKATANI, K., BAUMGARTNER, G. \& CAVICCHIOLI, M., 1997, Ecologia de ovos e larvas de peixes. In: A. A. Agostinho, A. E. de M. Vazzoler \& N. M. Hahn (eds.), A planície de inundação do Alto Rio Paraná. EdUEM, Maringá, PR, pp.281-306.

PAULY, D., 1980, On the interrelationships between natural mortality, growth parameters and mean environmental temperature in 175 fish stock. International Council for the Exploration of the Sea, 39: 175-192.

PAULY, D., 1987, A review of ELEFAN system for analysis of length-frequency data in fish and aquatics invertebrates. In: D. Pauly \& G. R. Morgan (eds.), Length based methods in fisheries research. ICLARM Conference Proccedings, 13: 7-34.

PCBAP - Plano de Conservação da Bacia do Alto Paraguai. Projeto Pantanal, 1997, Progama Nacional do Meio Ambiente/PNMA. Ministério do Meio Ambiente, Recursos Hídricos e Amazônia Legal, Brasília, Brasil, 3ํvol.

PETRERE Jr., M., 1983, Yeild per recruit of the tambaqui, Colossoma macropomum Curvier, in the Amazonas State, Brazil. J. Fish Biol., 22: 133-144.

SPARRE, P. \& VENEMA, S. C., 1997, Introdução à avaliação de mananciais de peixes tropicais. Parte 1: Manual, FAO, 404p.

SSENTONGO, G. W. \& LARKIN, P. A., 1973, Some simple methods of estimating mortality rates of exploited fish populations. J. Fish. Res. Bd. Can., 30: 695-698.

WELCOME, R. L., 1979, Fisheries ecology of floodplain rivers. London Logman, 317p. 